\title{
Resistance to Triadimefon and Benomyl: Dynamics and Impact on Managing Cucurbit Powdery Mildew
}

Margaret Tuttle McGrath and Nina Shishkoff, Department of Plant Pathology, Long Island Horticultural Research and Extension Center, Cornell University, 3059 Sound Avenue, Riverhead, New York, 11901-1098

\begin{abstract}
McGrath, M. T., and Shishkoff, N. 2001. Resistance to triadimefon and benomyl: Dynamics and impact on managing cucurbit powdery mildew. Plant Dis. 85:147-154.

Frequency of fungicide-resistant strains of Podosphaera xanthii on pumpkins in New York before treatment varied from 3 to $80 \%$ for the demethylation inhibiting (DMI) fungicide triadimefon and from 0 to $48 \%$ for the benzimidazole fungicide benomyl between 1993 and 1996. When the initial frequency of triadimefon-resistant strains was less than $55 \%$, one application of triadimefon plus chlorothalonil was effective. This application was made after reaching the action threshold of one leaf with powdery mildew symptoms per 50 old leaves (defined as the oldest third of the foliage). The frequency of triadimefon-resistant strains increased from 3 to $71 \%$ by 20 days after the first fungicide application in 1993. Triadimefon in the second application did not contribute to control. Loss of efficacy was due to resistance because, compared with triadimefon-treated pumpkins, pumpkins treated with other systemic fungicides were less severely infected by powdery mildew on abaxial leaf surfaces where the companion multi-site contact fungicide contributes little to control. Triadimefon was not effective in 1995 when $80 \%$ of the pathogen population was resistant before treatment. Benomyl was effective in 1995, but not in 1996 when $48 \%$ of the isolates tested were resistant to both benomyl and triadimefon before treatment. An in-field seedling assay was developed to determine local occurrence of resistant strains before the first treatment was needed. Although sensitivity of the pathogen population to the DMI fungicides myclobutanil and propiconazole also decreased after they were applied, these fungicides were more effective than triadimefon.
\end{abstract}

Additional keywords: ergosterol biosynthesis inhibiting fungicides, Sphaerotheca fuliginea, Sphaerotheca fusca, sterol biosynthesis inhibiting fungicides

Application of fungicides is the principal management practice for cucurbit powdery mildew, a major production problem in most areas of the world (24). Few or no cultivars of summer squash, winter squash, gourd, pumpkin, and watermelon with resistance to powdery mildew are available. Systemic fungicides are needed to obtain adequate protection of abaxial leaf surfaces, where conditions are more favorable for development of the pathogen, Podosphaera (sect. Sphaerotheca) xanthii (Castagne) U. Braun \& N. Shishkoff (28), than on adaxial surfaces (16). Unfortunately, pathogen strains occur throughout the United States with resistance to the demethylation inhibiting (DMI) fungicide triadimefon and to the benzimidazole fungicide benomyl (23). Despite widespread occurrence of strains highly resistant to triadimefon, this fungicide effectively suppressed powdery mildew in 1991 and 1992 because the frequency of resistant strains

Corresponding author: M. T. McGrath

E-mail: mtm3@cornell.edu

Accepted for publication 9 October 2000

Publication no. D-2000-1127-04R

(C) 2001 The American Phytopathological Society was low at the start of disease development (15). Following treatment, the pathogen population shifted to predominantly resistant strains, and consequently triadimefon did not provide full-season control (15). Growers applying triadimefon several times to a crop may not obtain control benefit from the later applications because of resistance.

Effective disease control following development of resistance has been possible with some diseases. For apple scab the best strategy for managing resistance to the DMI fungicide fenarimol and achieving good disease control was use of a high rate of fenarimol in a mixture with a multi-site contact fungicide (10). Both the high rate and the contact fungicide delayed the rate of resistance development during a growing season. Low rates were the most important driving force for selection of resistant isolates.

The main goal of the current study was to examine the yearly dynamics of resistance to fungicides registered at the time as they relate to control of cucurbit powdery mildew on pumpkins. Preliminary reports of part of this work have been made $(13,14,17,19,21)$.

\section{MATERIALS AND METHODS}

A field experiment with seven to nine fungicide treatments applied to pumpkins, replicated four times in a random block design, was performed in each of four years. Powdery mildew severity and fungicide sensitivity were monitored within seasons, and quality and quantity of fruit were evaluated at harvest.

Cultural practices. Field experiments were conducted on Haven loam and Riverhead sandy loam soils at the Long Island Horticultural Research and Extension Center. Fertilizer (10-10-10 N-P-K) was preplant broadcast, then incorporated at a rate of $1,120 \mathrm{~kg} / \mathrm{ha}$. A semi-bush pumpkin cultivar (Spirit or Wizard) was directseeded on 24 June 1993, 15 June 1994, 22 June 1995, and 27 June 1996. Plots were 7 $\times 11$ to $14 \mathrm{~m}$ and each contained four rows of 16 to 20 plants. Insect pests and weeds were managed as needed by applying insecticides and herbicides, mechanically cultivating, and hand-weeding (13,14, 17,21). The fields were overhead irrigated as needed $(13,14,17,21)$.

Fungicide treatments. Treatments were comprised of the following fungicides: chlorothalonil at $2.81 \mathrm{~kg} / \mathrm{ha}$ as Bravo 720 (ISK Biosciences, Mentor, $\mathrm{OH}$; presently produced by Zeneca Ag Products, Wilmington, DE) in 1993 and at $2.6 \mathrm{~kg} / \mathrm{ha}$ as Bravo Ultrex from 1994 to 1996, triadimefon at $134 \mathrm{~g} / \mathrm{ha}$ plus chlorothalonil at 2.5 $\mathrm{kg} / \mathrm{ha}$ as Reach (ISK Biosciences), benomyl at $560 \mathrm{~g} / \mathrm{ha}$ as Benlate 50WP (E. I. DuPont de Nemours, Wilmington, DE), myclobutanil at $56 \mathrm{~g} / \mathrm{ha}$ as Nova 40WP (Rohm \& Haas, Philadelphia, PA), propiconazole at $117 \mathrm{~g} / \mathrm{ha}$ as Tilt $41.8 \mathrm{GL}$ (Novartis Crop Protection, Greensboro, $\mathrm{NC}$ ) in 1993 and at $63 \mathrm{~g} / \mathrm{ha}$ as Tilt 45WP in 1995, triflumizole at $210 \mathrm{~g} / \mathrm{ha}$ as Procure 50WP (Uniroyal Chemical, Middlebury, $\mathrm{CT}$ ), and kresoxim-methyl at $84 \mathrm{~g} / \mathrm{ha}$ as Sovran F 50WG (BASF, Parsippany, NJ). Bravo, Benlate, and Reach were registered for application to control cucurbit powdery mildew at the time of this study. Triadimefon was used at the highest labeled rate.

Treatments listed in Table 1 were applied to plots. The standard fungicide program evaluated was the systemic fungicide triadimefon applied on a 14-day schedule with the broad-spectrum contact fungicide chlorothalonil applied on a 7-day schedule. This was accomplished by applying the pre-mix of triadimefon plus chlorothalonil alternately with chlorothalonil alone. All but one treatment was initiated after reaching the action threshold of one leaf with one or more colonies of powdery 
mildew per 50 old leaves examined in each plot (16). Old leaves were examined weekly for symptoms beginning when fruit were starting to form. The examined leaves were selected from the oldest third of the foliage based on leaf appearance and canopy position. Treatments included triadimefon applied one to four times in the standard fungicide program to assess the efficacy of successive triadimefon applications. The action threshold was reevaluated in 1993 by including treatments started before detection (preventive schedule), or started 1 or 2 weeks after reaching the threshold. We evaluated 7- and 14-day application schedules. A mid-season fungicide program (four applications from late July to mid August) was compared with a full-season program (six applications). Benomyl was included in some treatments. Additional treatments included use of new fungicides not registered at the time in the United States to determine when triadimefon resistance compromised efficacy. These included the strobilurin fungicide kresoxim-methyl and the DMI fungicides propiconazole, myclobutanil, and triflumizole.
A tractor-mounted boom sprayer delivering 374 liters/ha at $469 \mathrm{kPa}$ was used in 1993, 1994, and 1995. A sprayer delivering $935 \mathrm{~L} / \mathrm{ha}$ at $2,413 \mathrm{kPa}$ was used in 1996. Treatments were applied on six dates in 1993 (1, 9, 12, 20, 27 August; and 4 September), seven dates in 1994 (2, 9, 17, 24, 30 August; and 7, 14 September), six dates in 1995 (31 July; 8, 15, 22, 29 August; and 7 September), and five dates in 1996 (16, 23, 30 August; and 5, 15 September).

Powdery mildew assessments. Severity on both adaxial and abaxial leaf surfaces was assessed approximately weekly using

Table 1. Effect of fungicide program on powdery mildew development in pumpkin on Long Island, New York, in 1993 to 1996

\begin{tabular}{|c|c|c|c|c|c|c|}
\hline \multirow[b]{3}{*}{ Year/fungicide $^{\mathrm{u}}$ (application time ${ }^{\mathrm{v}}$ ) } & \multicolumn{6}{|c|}{ Powdery mildew severity ( $\%$ leaf coverage) } \\
\hline & \multicolumn{3}{|c|}{ Adaxial leaf surface ${ }^{t}$} & \multicolumn{3}{|c|}{ Abaxial leaf surface ${ }^{t}$} \\
\hline & 63 to 75 DAP $^{\mathrm{w}}$ & 70 to 83 DAP $^{w}$ & $\mathbf{A U D P C}^{\mathrm{x}}$ & 63 to 75 DAP & 70 to 83 DAP & AUDPC $^{\mathrm{x}}$ \\
\hline \multicolumn{7}{|l|}{ 1993: Action threshold reached by 48 DAP $^{v}$} \\
\hline Nontreated & $12.6 \mathrm{~b}^{\mathrm{y}}$ & $40.4 \mathrm{~b}$ & $225.9 \mathrm{c}$ & $14.3 \mathrm{~d}$ & $55.7 \mathrm{e}$ & $293.0 \mathrm{f}$ \\
\hline $\mathrm{T}(38,57,72)+\mathrm{C}(38,46,57,64,72)$ & $0.0 \mathrm{a}$ & $0.0 \mathrm{a}$ & $0.4 \mathrm{a}$ & $0.5 \mathrm{~b}$ & $16.0 \mathrm{~cd}$ & $59.1 \mathrm{c}$ \\
\hline $\mathrm{T}(49,64)+\mathrm{C}(49,57,64,72)$ & $0.0 \mathrm{a}$ & $0.0 \mathrm{a}$ & $0.6 \mathrm{a}$ & $0.7 \mathrm{~b}$ & $14.7 \mathrm{c}$ & $56.8 \mathrm{c}$ \\
\hline $\mathrm{T}(49)+\mathrm{C}(49,57,64,72)$ & $0.0 \mathrm{a}$ & $0.0 \mathrm{a}$ & $0.2 \mathrm{a}$ & $0.6 \mathrm{~b}$ & $22.0 \mathrm{cde}$ & $81.4 \mathrm{~cd}$ \\
\hline $\mathrm{T}(57,72)+\mathrm{C}(57,64,72)$ & $1.0 \mathrm{~b}$ & $1.2 \mathrm{~b}$ & $17.5 \mathrm{~b}$ & $3.2 \mathrm{c}$ & $39.2 \mathrm{de}$ & 172.4 ef \\
\hline $\mathrm{T}(64)+\mathrm{C}(64,72)$ & $3.2 \mathrm{~b}$ & $6.1 \mathrm{~b}$ & $48.4 \mathrm{~b}$ & $5.3 \mathrm{~cd}$ & 26.8 cde & $134.3 \mathrm{de}$ \\
\hline Myclobutanil $(49,64)+$ C $(49,57,64,72)$ & $0.0 \mathrm{a}$ & $0.0 \mathrm{a}$ & $0.5 \mathrm{a}$ & $0.1 \mathrm{a}$ & $0.3 \mathrm{~b}$ & $1.6 \mathrm{a}$ \\
\hline $\mathrm{P}$ at $0.28 \mathrm{~kg} / \mathrm{ha}(49,64)+\mathrm{C}(49,57,64,72)$ & $0.0 \mathrm{a}$ & $0.0 \mathrm{a}$ & $0.2 \mathrm{a}$ & $0.1 \mathrm{a}$ & $0.1 \mathrm{a}$ & $0.9 \mathrm{a}$ \\
\hline $\mathrm{P}$ at $0.14 \mathrm{~kg} / \mathrm{ha}(49,64)+\mathrm{C}(49,57,64,72)$ & $0.0 \mathrm{a}$ & $0.0 \mathrm{a}$ & $0.3 \mathrm{a}$ & $0.1 \mathrm{a}$ & $0.5 \mathrm{~b}$ & $4.2 \mathrm{~b}$ \\
\hline Probability $>F$ & 0.0001 & 0.0001 & 0.0001 & 0.0001 & 0.0001 & 0.0001 \\
\hline \multicolumn{7}{|l|}{ 1994: Action threshold reached by $47 \mathrm{DAP}^{\mathrm{v}}$} \\
\hline Nontreated & $10.2 b^{y}$ & $3.1 \mathrm{a}^{\mathrm{z}}$ & $102.0 \mathrm{a}$ & $22.1 \mathrm{~d}$ & $13.7 \mathrm{bc}^{2}$ & $288 \mathrm{abc}$ \\
\hline $\mathrm{T}(48,63,76,91)+\mathrm{C}(48,55,63,70,76,84,91)$ & $1.3 \mathrm{a}$ & $1.4 \mathrm{a}$ & $25.3 \mathrm{bc}$ & $16.6 \mathrm{~cd}$ & $32.2 \mathrm{~d}$ & $436 \mathrm{a}$ \\
\hline $\mathrm{T}(48,63)+\mathrm{C}(48,55,63,70,76,84,91)$ & $0.7 \mathrm{a}$ & $2.2 \mathrm{a}$ & $28.4 \mathrm{bc}$ & $8.4 \mathrm{bc}$ & $28.2 \mathrm{~d}$ & $318 \mathrm{ab}$ \\
\hline $\mathrm{T}(48)+\mathrm{C}(48,55,63,70,76,84,91)$ & $0.9 \mathrm{a}$ & $1.7 \mathrm{a}$ & $43.4 \mathrm{~b}$ & $12.0 \mathrm{~cd}$ & $23.0 \mathrm{~cd}$ & $291 \mathrm{abc}$ \\
\hline $\mathrm{P}(48,63,76,91)+\mathrm{C}(48,55,63,70,76,84,91)$ & $0.5 \mathrm{a}$ & $0.2 \mathrm{a}$ & $4.2 \mathrm{c}$ & $0.6 \mathrm{a}$ & $3.0 \mathrm{a}$ & $23 \mathrm{~d}$ \\
\hline$P(48,63)+C(48,55,63,70,76,84,91)$ & $0.7 \mathrm{a}$ & $0.7 \mathrm{a}$ & $7.8 \mathrm{bc}$ & $0.4 \mathrm{a}$ & $8.0 \mathrm{~b}$ & $77 \mathrm{~cd}$ \\
\hline $\mathrm{P}(48,63,76,91)$ & $0.4 \mathrm{a}$ & $0.1 \mathrm{a}$ & $4.4 \mathrm{bc}$ & $0.5 \mathrm{a}$ & $1.6 \mathrm{a}$ & $34 \mathrm{~cd}$ \\
\hline Probability $>F$ & 0.0001 & 0.2958 & 0.0050 & 0.0001 & 0.0001 & 0.0148 \\
\hline \multicolumn{7}{|l|}{ 1995: Action threshold reached by 35 DAP $^{v}$} \\
\hline Nontreated (control) & $56.7 \mathrm{a}^{\mathrm{y}}$ & $82.3 \mathrm{a}$ & $789.7 \mathrm{a}$ & $55 \mathrm{a}$ & 85 & $762 \mathrm{a}$ \\
\hline $\mathrm{T}(39,54,68)+\mathrm{C}(39,47,54,61,68,77)$ & $2.5 \mathrm{c}$ & $3.7 \mathrm{c}$ & $43.1 \mathrm{~d}$ & $41 \mathrm{ab}$ & 77 & $612 a b$ \\
\hline $\mathrm{T}(39,54)+\mathrm{C}(39,47,54,61,68,77)$ & $2.3 \mathrm{c}$ & $2.9 \mathrm{c}$ & $32.7 \mathrm{~d}$ & $47 \mathrm{a}$ & 63 & $609 a b$ \\
\hline $\mathrm{T}(39)+\mathrm{C}(39,47,54,61,68,77)$ & $9.3 \mathrm{bc}$ & $7.4 \mathrm{bc}$ & $120.7 \mathrm{bcd}$ & $50 \mathrm{a}$ & 76 & $681 \mathrm{a}$ \\
\hline $\mathrm{T}(39,54)+\mathrm{C}(39,47,54,61)$ & $4.7 \mathrm{bc}$ & $10.4 \mathrm{bc}$ & $92.2 \mathrm{~cd}$ & $45 \mathrm{a}$ & 81 & $655 \mathrm{a}$ \\
\hline $\mathrm{T}(39,54)+\mathrm{C}(39,54,68)$ & $20.8 \mathrm{~b}$ & $19.3 \mathrm{~b}$ & $250.6 \mathrm{~b}$ & $48 \mathrm{a}$ & 78 & 663 a \\
\hline $\mathrm{T}(39)+$ Benomyl $(54)+\mathrm{C}(39,47,54,61,68,77)$ & $17.4 \mathrm{bc}$ & $9.1 \mathrm{bc}$ & $191.4 \mathrm{bc}$ & $26 \mathrm{bc}$ & 69 & $464 \mathrm{~b}$ \\
\hline$P(39,54,68)+C(39,47,54,61,68,77)$ & $2.8 \mathrm{bc}$ & $5.0 \mathrm{c}$ & $41.1 \mathrm{~d}$ & $23 \mathrm{c}$ & 67 & $426 \mathrm{~b}$ \\
\hline Probability $>F$ & 0.0001 & 0.0001 & 0.0001 & 0.0089 & 0.29 & 0.0209 \\
\hline \multicolumn{7}{|l|}{ 1996: Action threshold reached by $49 \mathrm{DAP}^{\mathrm{v}}$} \\
\hline Nontreated & $2.72 \mathrm{a}^{\mathrm{x}}$ & $0.87 \mathrm{a}$ & $28.5 \mathrm{a}$ & $3.69 \mathrm{a}$ & $3.57 \mathrm{ab}$ & $54.7 \mathrm{a}$ \\
\hline$T(50,64)+C(50,57,64,70,80)$ & $0.00 \mathrm{~b}$ & $0.11 \mathrm{~b}$ & $0.4 \mathrm{~b}$ & $0.26 \mathrm{bc}$ & $3.08 \mathrm{ab}$ & $14.2 \mathrm{bc}$ \\
\hline $\mathrm{T}(50)+$ Benomyl $(64)+\mathrm{C}(50,57,64,70,80)$ & $0.01 \mathrm{~b}$ & $0.13 \mathrm{~b}$ & $0.5 \mathrm{~b}$ & $0.86 \mathrm{~b}$ & $2.08 \mathrm{~b}$ & $18.6 \mathrm{bc}$ \\
\hline Benomyl (50)+ T $(64)+C(50,57,64,70,80)$ & $0.02 \mathrm{~b}$ & $0.18 \mathrm{~b}$ & $1.0 \mathrm{~b}$ & $0.83 \mathrm{~b}$ & $4.57 \mathrm{a}$ & $24.3 \mathrm{ab}$ \\
\hline Benomyl $(50,64)+\mathrm{T}(57,70)+\mathrm{C}(50,57,64,70,80)$ & $0.01 \mathrm{~b}$ & $0.05 \mathrm{~b}$ & $0.3 \mathrm{~b}$ & $0.16 \mathrm{bc}$ & $1.90 \mathrm{~b}$ & $8.8 \mathrm{c}$ \\
\hline Triflumizole $(50,64,80)$ & $0.03 \mathrm{~b}$ & $0.03 \mathrm{~b}$ & $0.4 \mathrm{~b}$ & $0.12 \mathrm{bc}$ & $0.50 \mathrm{c}$ & $3.1 \mathrm{~d}$ \\
\hline Kresoxim-methyl $(50,64,80)$ & $0.02 \mathrm{~b}$ & $0.00 \mathrm{~b}$ & $0.4 \mathrm{~b}$ & $0.09 \mathrm{c}$ & $0.60 \mathrm{c}$ & $3.1 \mathrm{~d}$ \\
\hline Probability $>F$ & 0.0011 & 0.0009 & 0.0001 & 0.0001 & 0.0004 & 0.0001 \\
\hline
\end{tabular}

${ }^{\mathrm{t}}$ Exact colony counts were made when possible and severity was estimated using the conversion factor of 30 colonies/leaf $=1 \%$. A logarithmic transformation was used when necessary to stabilize variance. This table contains de-transformed means.

${ }^{u}$ Fungicides tested included chlorothalonil (C), triadimefon $(\mathrm{T})$, and propiconazole $(\mathrm{P})$.

${ }^{\vee}$ Application times are presented as days after planting (DAP). In 1993, 38 DAP $=1$ August, $46=9$ August, $49=12$ August, $57=20$ August, $64=27$ August, and $72=4$ September. Applications were started either before detection on 38 DAP, or 1, 9, or 16 days after the action threshold was reached (49, 57 and 64 DAP, respectively). In 1994, $48=2$ August, $55=9$ August, $63=17$ August, $70=24$ August, $76=30$ August, $84=7$ September, and $91=$ 14 September. In 1995, $39=31$ July, $47=8$ August, $54=15$ August, $61=22$ August, $68=29$ August, and $77=7$ September. In 1996, $50=16$ August, $57=23$ August, $64=30$ August, $70=5$ September, and $80=15$ September.

${ }^{\text {w}} 63$ to 75 DAP is 26 August 1993 (63 DAP), 29 August 1994 (75 DAP), 24 August 1995 (63 DAP), and 29 August 1996 (63 DAP). 70 to 83 DAP is 2 September 1993 (70 DAP), 6 September 1994 (83 DAP), 31 August 1995 (70 DAP), and 11 September 1996 (76 DAP).

${ }^{x}$ AUDPC was calculated for severity from 11 August to 2 September 1993 (48 to 70 DAP), 27 July to 6 September 1994 (42 to 83 DAP), 27 July to 31 August 1995 (35 to 70 DAP), and 5 August to 11 September 1996 (39 to 76 DAP).

${ }^{y}$ For each year, numbers in a column with a letter in common are not significantly different according to Fisher's Protected least significant difference $(P=$ $0.05)$.

${ }^{\mathrm{z}}$ The severity ratings for the control group during September were low because many leaves had senesced prematurely due to powdery mildew. 
procedures described previously (16). Area under the disease progress curve (AUDPC) was calculated for severity from 11 August through 2 September 1993, from 27 July through 6 September 1994, from 27 July through 31 August 1995, and from 5 August through 11 September 1996.

Yield measurements. Fruit were counted, weighed, and quality evaluated in mid October 1993 and on 29 September 1995. Only fruit from nontreated and triadimefon plus chlorothalonil treated plots were harvested in 1995 . Fruit diameter was determined for 12 representative fruit per plot on 3 October 1996. Fruit weight was estimated from diameter with a linear regression equation derived from representative fruit. Fruit evaluation included color in 1993 and handle (peduncle) condition in all years. Yield was not examined intensively because this was done in a previous study and weighing fruit and assessing fruit quality for large experiments is a timeconsuming process (16). Handle condition was evaluated in all experiments because it can be done quickly and it is the yield parameter most affected by powdery mildew (16).

Fungicide sensitivity assays. A leafdisk bioassay was used as described previously (23) to determine fungicide sensitivity. Isolates of $P$. xanthii were collected at the start of powdery mildew development from non-fungicide-treated plots on 11 August 1993 (30 isolates), 6 August 1994 (23 isolates), 1 August 1995 (10 isolates), and 20 August 1996 (25 isolates). Isolates were collected on 1 September 1993 (14 isolates), 19 August 1994 (19 isolates), 18 August 1995 (14 isolates), and 19 September 1996 from plots that had been treated once or twice with triadimefon. Isolates also were collected on 20 September 1993 (60 isolates) from throughout the experimental field and on 2 September 1995 (13 isolates) from plots treated once with triadimefon and once with benomyl. Sensitivity was determined to triadimefon for all isolates, to benomyl for most isolates, and to propiconazole and myclobutanil for isolates collected in 1993. Sensitivity to propiconazole also was determined for isolates collected on 19 September 1994 (10 isolates) from plots that had been treated four times with propiconazole.

The fungicide concentrations used in the leaf disk assay were modified during this study in part based on results obtained. Triadimefon (Bayleton 50DF, Bayer, Kansas City, MO) was used at $50 \mu \mathrm{g} / \mathrm{ml}(6.25$, $12.5,25$, and $100 \mu \mathrm{g} / \mathrm{ml}$ were also used in some tests). Benomyl (Benlate 50DF) was used at $200 \mu \mathrm{g} / \mathrm{ml}$. Isolates able to tolerate triadimefon at $50 \mu \mathrm{g} / \mathrm{ml}$ and benomyl at $200 \mu \mathrm{g} / \mathrm{ml}$ were considered resistant to these fungicides. Myclobutanil (RH-3866 technical fungicide, Rohm \& Haas) was used at $2 \mu \mathrm{g} / \mathrm{ml}(0.1,0.2,1$, and $20 \mu \mathrm{g} / \mathrm{ml}$ were included in some tests). Propiconazole (Tilt 3.6E) was used at 0.05 and 0.5 $\mu \mathrm{g} / \mathrm{ml}(0.01$ and $5 \mu \mathrm{g} / \mathrm{ml}$ were included in some tests).

An in-field fungicide sensitivity assay was developed and tested in 1995 and 1996. This assay involved using spring plantings, where powdery mildew appears first, to predict occurrence of resistance in main-season plantings before the action threshold is reached. Growth chambergrown 'Seneca Prolific' summer squash seedlings with 2 to 3 expanded leaves (19 days after seeding) were used. Apical shoots with unexpanded leaves were removed. Seedlings were either left untreated or dipped in a solution of triadimefon at 50 $\mu \mathrm{g} / \mathrm{ml}$ or benomyl at $200 \mu \mathrm{g} / \mathrm{ml}$. When dry treated and untreated seedlings, when dry, were placed next to field-grown summer squash with powdery mildew. They were put in a greenhouse 3 days later. Powdery mildew colonies were counted when visible. Frequency of resistance to triadimefon or benomyl was estimated from the average number of powdery mildew colonies on treated and nontreated plants. Assays were conducted on 25 July 1995 and 6 August 1996.

Data analysis. Analysis of variance for a random complete block experimental design was performed with SuperANOVA version 1.1 for the Macintosh (Abacus Concepts, Berkeley, CA). Disease severity and area under the disease progress curve (AUDPC) data were transformed to natural logarithms where necessary to obtain constant variance based on scattergrams of residuals versus fitted $Y$ before analysis of variance. Fisher's protected least significant difference was used to compare treatments $(P=0.05)$.

\section{RESULTS}

1993. The growing season was unusually hot and dry. Consequently, plants grew slowly in July and the onset of powdery mildew was delayed compared with previous years. Disease development, however, was rapid following onset. The action threshold of one leaf out of 50 old leaves with powdery mildew was exceeded considerably 1 day before the first fungicide application because of rapid initial disease development. Symptoms were found on $66 \%$ of the leaves examined 48 days after planting (DAP) (11 August). An average of 7.7 colonies/leaf were found on affected leaves. Despite this high disease level, powdery mildew was controlled as effectively with the integrated pest management (IPM) schedule (four applications) as with the preventive schedule (five applications) (Table 1). Powdery mildew was not controlled as well when fungicide applications were started 1 or 2 weeks after reaching the action threshold.

After triadimefon plus chlorothalonil was applied, the frequency of strains of $P$. xanthii resistant to triadimefon increased and efficacy declined. Frequency shifted from $3 \%$ on 48 DAP to $71 \%$ on 69 DAP for pumpkin treated with triadimefon 49 and 64 DAP (Table 2). The one resistant isolate out of 30 collected 48 DAP from non-fungicide-treated plants could have been selected for by fungicide treatment as it was located between two plots treated with triadimefon plus chlorothalonil 38 DAP according to a preventive schedule. The first application of triadimefon plus chlorothalonil 49 DAP was effective. Powdery mildew was significantly less severe on abaxial leaf surfaces of treated than nontreated leaves 2 weeks later (Table 1 , 63 to 75 DAP). Triadimefon in the second application 64 DAP did not contribute significantly to control. There were no significant differences in disease severity 70 DAP on plants sprayed once or twice with triadimefon plus four times with chlorothalonil (Table 1, 70 to 83 DAP). Both myclobutanil and propiconazole applied in combination with chlorothalonil were more effective than triadimefon plus chlorothalonil on abaxial leaf surfaces, which indicates that the decline in efficacy of triadimefon was most likely due to resistance. Sensitivity of the powdery mildew population to myclobutanil and propiconazole also changed following fungicide treatment. Before treatment, the maximum concentrations tolerated by most isolates tested $(77 \%)$ were $0.1 \mu \mathrm{g}$ of myclobutanil per $\mathrm{ml}$ and $0.05 \mu \mathrm{g}$ of propiconazole per $\mathrm{ml}$. The frequency of isolates able to grow on leaf disks treated with $2 \mu \mathrm{g}$ of myclobutanil per ml was $10 \% 48$ DAP and $93 \% 69$ DAP. For $0.5 \mu \mathrm{g}$ of propiconazole per $\mathrm{ml}$, the frequency shifted from $0 \%$ to $93 \%$. All triadimefon-resistant isolates were more tolerant than sensitive isolates to these other DMI fungicides, tolerating 2 $\mu \mathrm{g}$ of myclobutanil per $\mathrm{ml}$ and $0.5 \mu \mathrm{g}$ of propiconazole per ml. Only $14 \%$ of the isolates able to tolerate $2 \mu \mathrm{g} / \mathrm{ml}$ myclobutanil and $0.5 \mu \mathrm{g}$ of propiconazole per $\mathrm{ml}$ were sensitive to triadimefon. Isolates collected 88 DAP (20 September) were tested at higher concentrations: $10 \%$ tolerated $20 \mu \mathrm{g}$ of myclobutanil per $\mathrm{ml}$ and $41 \%$ tolerated $5 \mu \mathrm{g}$ of propiconazole per $\mathrm{ml}$. Efficacy of myclobutanil and propiconazole was not affected by these less sensitive strains. No benomyl-resistant isolates were detected.

Powdery mildew severity increased substantially by 92 DAP, especially on abaxial leaf surfaces (Fig. 1). For most treatments, this was 20 days after the last chlorothalonil application and 28 days after the last triadimefon, myclobutanil, or propiconazole application. Severity on adaxial leaf surfaces was $7.6 \%$ for triadimefon and 2 to $4.5 \%$ for myclobutanil and propiconazole treatments; severity on abaxial surfaces was $55 \%$ and 36 to $61 \%$, respectively. All leaves in nontreated plots had died.

Controlling powdery mildew significantly affected fruit quality but not quantity. Control plots had the highest percentage of fruit with partially to com- 
pletely decayed handles (64\%) and of fruit with an undesirable yellow-orange color $(42 \%)$. Among the treatments, the percentage of fruit with decayed handles was lowest for myclobutanil (5\%) and highest (28 to $29 \%$ ) for the triadimefon-pluschlorothalonil treatments initiated 1 or 2 weeks after reaching the action threshold. There were no significant differences among treatments in number or total weight of fruit. Fruit number and weight ranged from 13,195 fruit/ha and 55.8 tons/ha for the control to 14,228 to 15,021 fruit/ha and 62.3 to 72.7 tons/ha for myclobutanil and propiconazole treatments.

1994. Powdery mildew was detected in 35 of 40 plots on 42 DAP (27 July) and in all plots 47 DAP. Between these dates, the percentage of old leaves with symptoms increased from 6.5 to $33 \%$ and the average number of colonies per affected leaf increased from 1.9 to 19.8 . Fungicide treatments were started 48 DAP.

Although conditions were favorable for disease development, nontreated plants of cv. Wizard were less severely infected than nontreated plants of cv. Spirit in 1993 (Table 1). There was more disease in one section of the field that included part of all replications, resulting in more variation between plots for some treatments than in previous experiments. The plants in this section did not grow as well as in the other sections, probably due to lower moistureholding capacity of the soil.

Triadimefon-resistant isolates were common at the start of the epidemic: 12 of 26 isolates collected 52 DAP from nonfungicide-treated leaves tolerated $50 \mu \mathrm{g} / \mathrm{ml}$ (Table 2). Despite this level of resistance, the first application of triadimefon plus chlorothalonil 48 DAP was effective since there was significantly less powdery mildew on abaxial surfaces compared with nontreated leaves 62 DAP (Table 2). Selection for resistance occurred rapidly: $79 \%$ of the isolates tested after one application of triadimefon plus chlorothalonil were resistant (Table 2). Not surprisingly, there were no significant differences among the treatments with one, two, or four applications of triadimefon plus chlorothalonil (Table 1), and triadimefon did not control powdery mildew on abaxial surfaces at 70 DAP (Fig. 1). Development of resistance to triadimefon is the most likely explanation for greater disease severity on abaxial leaf surfaces of plants treated with triadimefon plus chlorothalonil than those treated with propiconazole beginning with the assessment 70 DAP, which was 7 days after the second application of these fungicides (Table 1). No benomyl-resistant isolates were detected.

Unlike triadimefon, more than one application of propiconazole improved powdery mildew control. Severity on abaxial leaf surfaces was significantly lower with four than with two applications of propiconazole plus chlorothalonil 83 DAP, 20 days after the second propiconazole application (Table 1). Propiconazole applied on a 14-day interval suppressed powdery mildew when applied alone as well as when applied with chlorothalonil on a 7-day interval, indicating that a 14-day schedule may be sufficient for disease control. Only chlorothalonil suppressed downy mildew, which developed late in the experiment and resulted in earlier leaf senescence in plots treated with propiconazole alone than in plots treated with chlorothalonil. Propiconazole caused minor puckering on less than $5 \%$ of treated leaves, but this growthregulator effect did not seem to affect yield.

Powdery mildew severity on abaxial surfaces of leaves treated with propiconazole increased substantially after 83 DAP. The average severity ratings for the plots evaluated 93 DAP, which was 2 days after the fourth application of propiconazole, were 2 and $1 \%$ for adaxial surfaces and and 1 and $37 \%$ for abaxial surfaces of leaves treated four times with propiconazole and triadimefon, respectively, plus chlorothalonil. This large increase in severity on abaxial surfaces of propiconazole-treated leaves, the difference in severity on the two leaf surfaces and the similarity in severity for propiconazole and triadimefon treatments suggests resistance to propiconazole had developed. However, $0.5 \mu \mathrm{m}$ of propiconazole per $\mathrm{ml}$ was the highest concentration tolerated by all isolates tested from plots treated four times with propiconazole.

1995. Powdery mildew was observed on the abaxial surface of $20 \%$ of the older leaves examined 35 DAP (27 July). Affected leaves had an average of 1.9 colonies. Treatments started 4 days later. Powdery mildew became more severe on nontreated plants in 1995 than in 1994.

Triadimefon resistance was higher before treatment $(80 \%)$ than in previous years (Table 2). Fungicide programs with triadimefon controlled powdery mildew on adaxial leaf surfaces but not on abaxial leaf surfaces (Table 1; Fig. 1) most likely because of resistance to triadimefon. The first application of triadimefon made 39 DAP did not affect disease development. The average number of colonies on abaxial leaf surfaces 48 DAP was 5.4 for the control and 3.1 to 4.9 for triadimefon plus chlorothalonil treatments. Nevertheless, disease severity was significantly less (1.2) for propiconazole than triadimefon. Additional applications of triadimefon did not contribute to control since there were no significant differences among fungicide

Table 2. Occurrence of fungicide resistant strains of Podosphaera xanthii at the start of powdery mildew development in pumpkin on Long Island, New York, in 1993 to 1996, effect of resistance on effectiveness of triadimefon for controlling powdery mildew on abaxial leaf surfaces, and effect of triadimefon use over one season on resistance and efficacy

\begin{tabular}{|c|c|c|c|c|c|c|}
\hline \multirow[b]{3}{*}{ Year/Triadimefon application ${ }^{w}$} & \multirow{2}{*}{\multicolumn{2}{|c|}{ 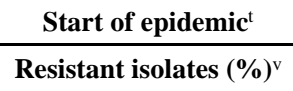 }} & \multirow[b]{3}{*}{ Severity $(\%)$ after $1 \operatorname{spray}^{x}$} & \multirow{2}{*}{\multicolumn{2}{|c|}{$\frac{\text { Middle of epidemic }^{\mathrm{u}}}{{\text { Resistant isolates }(\%)^{\mathrm{v}}}}$}} & \multirow[b]{3}{*}{ Severity (\%) after $2-3$ sprays } \\
\hline & & & & & & \\
\hline & Triadimefon & Benomyl & & Triadimefon & Benomyl & \\
\hline \multicolumn{7}{|l|}{1993} \\
\hline None & 3 & 0 & $14.3 \mathrm{~S}^{\mathrm{z}}$ & & & $56 \mathrm{~S}^{\mathrm{z}}$ \\
\hline 49,64 DAP & & & 0.7 & 71 & & 15 \\
\hline \multicolumn{7}{|l|}{1994} \\
\hline None & 39 & 0 & $4.3 \mathrm{~S}$ & & & $14 \mathrm{NS}$ \\
\hline $48,63,76,91 \mathrm{DAP}$ & & & 0.8 & 79 & & 19 \\
\hline \multicolumn{7}{|l|}{1995} \\
\hline None & 80 & 0 & $6.4 \mathrm{NS}$ & & & $85 \mathrm{NS}$ \\
\hline $39,54,68$ DAP & & & 4.2 & 73 & & 77 \\
\hline \multicolumn{7}{|l|}{1996} \\
\hline None & 52 & 48 & $4.6 \mathrm{~S}$ & 56 & 31 & $4 \mathrm{NS}$ \\
\hline 50,64 DAP & & & 0.3 & 66 & 66 & 3 \\
\hline
\end{tabular}

${ }^{t}$ Isolates were collected on 11 August 1993 (48 DAP), 6 August 1994 (52 DAP), 1 August 1995 (40 DAP), and 20 August 1996 (54 DAP).

u Isolates were collected on 1 September 1993 (69 DAP), 19 August 1994 (65 DAP), 18 August 1995 (57 DAP), and 19 September 1996 (84 DAP).

${ }^{v}$ Frequency of $P$. xanthii isolates that were able to grow on leaf disks treated with triadimefon at $50 \mu \mathrm{g} / \mathrm{ml}$ or with benomyl at $200 \mu \mathrm{g} / \mathrm{ml}$.

${ }^{\text {w }}$ Triadimefon was applied on a 14-day interval with chlorothalonil applied on a 7-day interval.

${ }^{x}$ Severity was assessed on 26 August 1993 (63 DAP), 16 August 1994 (62 DAP), 16 August 1995 (55 DAP), and 29 August 1996 (63 DAP).

y Severity was assessed on 2 September 1993 (70 DAP), 6 September 1994 (83 DAP), 31 August 1995 (70 DAP), and 11 September 1996 (76 DAP).

${ }^{\mathrm{z}} \mathrm{S}=$ Powdery mildew severities on triadimefon-treated and nontreated pumpkins were significantly different $(\mathrm{P}=0.05)$; NS = not significantly different. 
programs with one, two, or three applications of triadimefon with chlorothalonil applied on other treatment dates for a total of six fungicide applications (Table 1). The frequency of triadimefon-resistant strains did not increase after treatment from the initial high level of $80 \%$ (Table 2). The program with two applications of triadimefon plus three applications of chlorothalonil applied on a 14-day interval was not as effective for controlling powdery mildew on adaxial leaf surfaces as the program with two applications of triadimefon plus six applications of chlorothalonil applied on a 7-day fungicide interval.

A treatment with benomyl was included because benomyl-resistant strains had not been detected in 1993 or 1994 . None of the isolates collected before fungicide treatment were resistant to benomyl (Table 1). The application of benomyl 54 DAP was effective since severity on abaxial leaf surfaces 63 DAP was significantly less than in most other treatments that also included triadimefon and chlorothalonil (Table 1). Only one benomyl-resistant isolate was detected among the 13 isolates collected on 72 DAP from benomyl-treated plots. The treatment with benomyl, which included triadimefon and chlorothalonil, was as effective for controlling powdery mildew on abaxial leaf surfaces as propiconazole plus chlorothalonil (Table 1).

Fungicide treatment significantly affected fruit quality but not fruit weight. Only $56 \%$ of the fruit from control plots had firm handles that were not decaying, whereas there were good handles on $82 \%$ of the fruit from plants treated three times with triadimefon and six times with chlorothalonil. Therefore, control of powdery mildew on adaxial leaf surfaces provided by chlorothalonil resulted in better fruit quality.

1996. Powdery mildew was detected in 19 of 44 plots 39 DAP (5 August) and in all plots 49 DAP. Between these dates, the percentage of old leaves with symptoms increased from 1.7 to $15.9 \%$ and the average number of colonies per affected leaf increased from 1.2 to 1.7. Fungicide treatments were started 50 DAP.

Isolates resistant to triadimefon and benomyl were found prior to treatment (Table 2). Many isolates (48\%) were resistant to both fungicides; $4 \%$ were resistant to just triadimefon. Triadimefon or benomyl applied 50 DAP provided some disease suppression compared with the control: powdery mildew was significantly less severe on abaxial leaf surfaces 63 DAP (Table 1). Additional applications of either triadimefon or benomyl did not appear to be effective based on disease severity on abaxial leaf surfaces 76 DAP (11 September). None of the four treatments with these fungicides had significantly less powdery mildew than the control, and these treatments had significantly more powdery mildew than treatments with the
DMI fungicide triflumizole or the strobilurin fungicide kresoxim-methyl (Table 1, 70 to $83 \mathrm{DAP}$ ). Applying benomyl and/or triadimefon resulted in an increase in the frequency of isolates resistant to both fungicides. The frequency of isolates collected 84 DAP that were resistant to triadimefon was $56,66,76$, and $100 \%$ for nontreated, treated twice with triadimefon plus five times with chlorothalonil, treated once with triadimefon plus once with benomyl plus five times with chlorothalonil, and treated twice with triadimefon plus twice with benomyl plus five times with chlorothalonil, respectively. The frequency of isolates resistant to benomyl was 31,65 , 66 , and $100 \%$, respectively, for these treatments.
Assessing impact of powdery mildew on yield was hampered by occurrence of downy mildew. Pumpkins treated with triflumizole and kresoxim-methyl had significantly more defoliation due to downy mildew than pumpkins treated with chlorothalonil. Leaf death due to either disease led to vine collapse and decaying of fruit handles before harvest. There were no significant differences in fruit size.

In-field fungicide sensitivity assay. Powdery mildew colonies were visible 7 days after the seedlings were put in the field. The frequency of resistance was estimated to be $89 \%$ for triadimefon and 0\% for benomyl in 1995 and $43 \%$ for triadimefon and 29\% for benomyl in 1996.

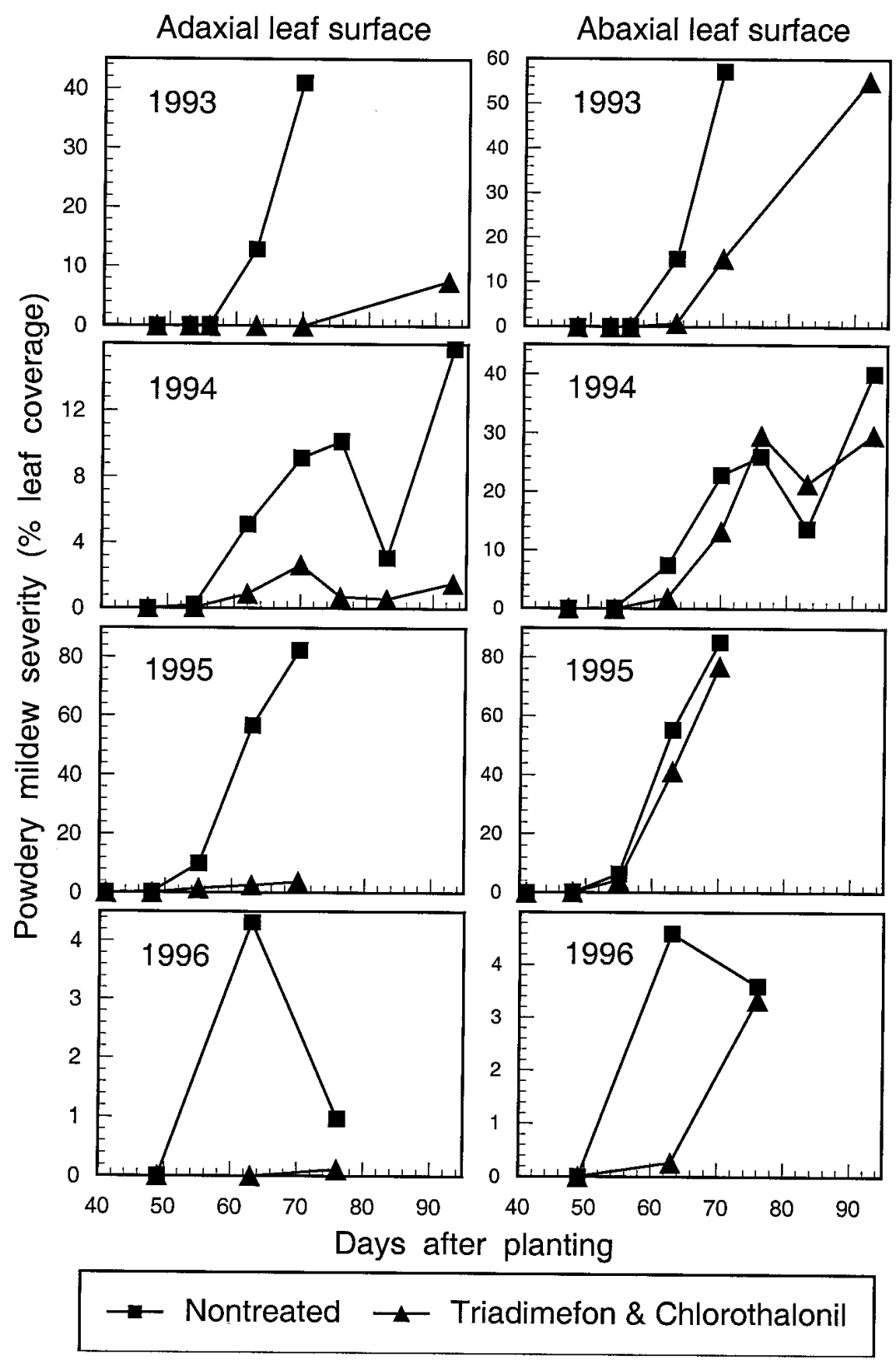

Fig. 1. Powdery mildew development in untreated pumpkin and pumpkin treated with the fungicides triadimefon and chlorothalonil. Application dates are listed in Table 1. Note that the scale varies among graphs. 


\section{DISCUSSION}

Dynamics of fungicide resistance. The frequency of resistant strains before treatment varied substantially from year to year. Triadimefon-resistant strains were uncommon in 1991 (0\%) (15), 1992 (0\%) (15), and 1993 (3\%), but common in 1994 through 1996 (39 to 80\%). In contrast, benomyl-resistant strains were common in 1991 and 1992 (10 to 77\%) (15), undetectable in 1993 to 1995 , then common again in $1996(48 \%)$. With this yearly variation, it is difficult to predict the efficacy of these fungicides based on the frequency of resistant strains the previous year. Yearly variation also appears to be occurring in other states. In Arizona triadimefonresistant strains were detected in 1993 (23); triadimefon (formulated as Bayleton) was ineffective in 1995 (11) but effective in 1996 (12). Growers' need for current information on resistance to tailor their fungicide program spurred development of an in-field fungicide sensitivity assay.

Variation among states in fungicide efficacy results indicates that occurrence of fungicide resistance varies among locations within a year as well as year to year. For example, in 1996, neither benomyl nor triadimefon used alone would have provided season-long control in this study because $48 \%$ of the pathogen population was resistant to both fungicides before treatment. In Delaware, however, benomyl was ineffective and triadimefon provided moderately good control (4). The large apparent difference in the pathogen population in these two nearby areas is unexpected considering the yearly source of the pathogen in northern states is thought to be southern production areas. Triadimefon was effective in at least one location south of New York and Delaware in 1996: triadimefon plus chlorothalonil was not significantly different from propiconazole, the most effective treatment, in Tennessee (27). Both benomyl and triadimefon alone were as effective as azoxystrobin (Quadris) and triflumizole in Arizona (12). Whereas in California, triadimefon was ineffective while myclobutanil (Rally) was effective (7).

Fungicide resistance and efficacy of triadimefon and benomyl. The first annual application of triadimefon plus chlorothalonil, made after powdery mildew detection, was effective when the initial frequency of triadimefon-resistant strains was as high as 52\%. In 1993, 1994, and 1996 , powdery mildew was significantly less severe on the abaxial leaf surfaces of triadimefon-treated leaves than on nontreated leaves 10 to 14 days after the first application. There were no significant differences in disease severity in 1995 when the initial frequency of triadimefonresistant strains was $80 \%$. Efficacy of systemic fungicides was assessed based on powdery mildew severity on abaxial surfaces because the contact fungicide chlorothalonil had been effective only on adaxial surfaces in previous experiments (16). The second application of triadimefon was not effective, as there were no significant differences in disease severity between plants sprayed once versus twice with triadimefon plus chlorothalonil in 1993 and 1994. Loss of efficacy was due to resistance because the frequency of triadimefon-resistant strains had increased to 71 to $79 \%$ by 16 to 17 days after the first fungicide application, and because powdery mildew was more severe on abaxial surfaces of leaves treated with triadimefon than on those treated with other fungicides. Consequently, season-long control was not obtained with triadimefon during this study. In contrast to triadimefon, more than one application of propiconazole contributed to powdery mildew control.

Benomyl contributed to disease control on abaxial leaf surfaces in 1995 but not in 1996. In both experiments, benomyl was used in a fungicide program with triadimefon and chlorothalonil. It was not tested in 1993 or 1994 because benomyl-resistant strains were common in 1991 and 1992 (15). Benomyl was effective in 1995 because resistance was at an undetectable level before treatment. Following this application, the frequency of benomylresistant strains increased to only $8 \%$. Benomyl did not improve the control achieved with triadimefon and chlorothalonil in 1996 because $48 \%$ of the population was resistant to benomyl before treatment and all of these isolates were also resistant to triadimefon. Only one application would be expected to be effective with this level of resistance, and using either triadimefon or benomyl would be expected to increase resistance to both since $92 \%$ of the resistant isolates were resistant to both fungicides.

Fungicide efficacy results from experiments conducted elsewhere in the United States from 1993 to 1996 are consistent with our findings in that triadimefon contributed little to cucurbit powdery mildew control, benomyl was moderately effective, and new systemic fungicides were very effective. In Oklahoma in 1994, triadimefon (as Bayleton) was ineffective, benomyl (Benlate) was effective, and myclobutanil (RH-3866) was more effective than benomyl (3). Resistance was suggested as the reason triadimefon was not more effective than chlorothalonil (Bravo) and was significantly less effective than myclobutanil in Michigan in 1994 (5). In 1995, triadimefon was significantly less effective than chlorothalonil while both triflumizole (Procure) and myclobutanil were effective (6). Triadimefon was one of the least effective treatments while myclobutanil was one of the most effective in Ohio in 1996 (26). In Arizona in 1995, triadimefon was ineffective while benomyl was effective (11). In this experiment myclobutanil (Rally) was not significantly more effective than benomyl.
In-field fungicide sensitivity assay. Placing fungicide-treated seedlings next to a spring planting of summer squash with powdery mildew was successfully used to determine occurrence of fungicide resistance before the action threshold was reached in pumpkin in 1996 and at the time of the first fungicide application in 1995 . Growers could use this information to tailor their fungicide program for any main season cucurbit crop and thereby minimize the chance of control failure due to fungicide resistance. The assay could have been conducted earlier in 1995 to obtain more time for fungicide selection. Both the infield seedling assay and the leaf-disk assay provided similar information about resistance. In 1995, both assays revealed that triadimefon-resistant strains were common $(\geq 80 \%)$ while benomyl-resistant strains were not detected. In 1996, both assays revealed that resistance to triadimefon and to benomyl were present before treatment and that the frequency of resistant individuals was low enough $(<50 \%)$ that either fungicide should provide some suppression of powdery mildew. The in-field assay was faster (7 to 10 days versus 20 days), less labor-intensive, and less expensive than the leaf-disk assay and required no specialized equipment. The leaf-disk assay, however, provides information about the fungicide sensitivity of individuals. Only the leafdisk assay revealed that most resistant isolates were resistant to both fungicides in 1996, thus applying one fungicide would increase resistance to both. This problem was partially overcome in subsequent infield assays by including a treatment with a combination of triadimefon and benomyl (M. McGrath, unpublished data). The infield assay has been used in the Cornell University Cucurbit IPM program (A. J. Seaman, personal communication).

Fungicide sensitivity and efficacy of myclobutanil and propiconazole. Although sensitivity to myclobutanil and to propiconazole also decreased after treatment, applied with chlorothalonil these fungicides were more effective than triadimefon plus chlorothalonil. Triadimefonresistant isolates were more tolerant than sensitive isolates to these other DMI fungicides, tolerating 2 to $20 \mu \mathrm{g}$ of myclobutanil per $\mathrm{ml}$ and 0.5 to $5 \mu \mathrm{g}$ of propiconazole per $\mathrm{ml}$. Cross resistance among these DMI fungicides was demonstrated previously (23). Only triadimefon efficacy was affected by occurrence of these resistant isolates because they are able to tolerate a much higher concentration of triadimefon $(200 \mu \mathrm{g} / \mathrm{ml})$ than myclobutanil or propiconazole (15). Similar differences in inherent activity of DMI fungicides have been detected with other pathogens (29). It appeared that resistance to propiconazole developed in 1994 because powdery mildew severity on abaxial surfaces of leaves treated with propiconazole increased from $3 \% 83$ DAP to $21 \% 93$ DAP (16 Septem- 
ber), which was 2 days after the fourth application. None of the isolates tested, however, were less sensitive to propiconazole than isolates tested previously. Perhaps propiconazole was not able to move well translaminarly in old leaves. There are other explanations for reduced fungicide efficacy such as application mixing error. Propiconazole plus chlorothalonil was not more effective than triadimefon plus chlorothalonil in 1995. This is more likely due to high disease pressure and using too low a rate of propiconazole $(63 \mathrm{~g} / \mathrm{ha})$ than due to fungicide resistance. Propiconazole was more effective when applied at 117 $\mathrm{g} / \mathrm{ha}$ in 1994.

IPM schedule and reduced-spray fungicide programs. Effective control of powdery mildew was achieved by initiating fungicide applications after reaching the action threshold of one leaf with powdery mildew colonies per 50 old leaves examined. Using this threshold to initiate fungicide programs was as effective as using a preventive program, confirming previous results (16). Powdery mildew was found in some plots 5 to 10 days before the threshold was reached in all plots in 1994 and 1996. The actual disease level when the threshold was reached ranged from an average of 8 to 33 out of 50 leaves with symptoms. The threshold was reached 47 to 49 DAP, except in 1995 when it was reached 35 DAP. The first application under the IPM schedule was made 1 to 4 days after the threshold was reached. Thus the current study also confirmed that there is time for detection and management response with this protocol. Although there is some time for response, it is prudent to scout weekly and to apply fungicides promptly. Powdery mildew was not controlled as effectively when treatment was delayed 1 or 2 weeks in 1993.

Impact on yield. Controlling powdery mildew had a significant impact on fruit quality but not quantity. When not adequately controlled, powdery mildew (and downy mildew in 1996) caused leaves to die prematurely which resulted in fruit being an undesirable yellow-orange, vines collapsing, and fruit handles decaying before harvest. Similar results were obtained in a previous study with pumpkin (16). In contrast, powdery mildew reduced fruit quantity with summer squash (22) and both fruit quality and quantity with muskmelon (20) in experiments conducted near the pumpkin experiments. Powdery mildew severity can increase rapidly after treatment is ended, as documented in 1993, which could impact yield if it occurs too soon before harvest.

Managing resistance. Using a DMI fungicide at the highest labeled rate or applying it with a multi-site contact fungicide with low resistance risk are two strategies for managing resistance and controlling disease. The rationales for these strategies are to control strains with intermediate sensitivity by using a high fungicide dose or to reduce the overall size of the pathogen population (including strains with reduced sensitivity) by using a contact fungicide. Each of these strategies has been effective for controlling apple scab with the DMI fungicide fenarimol (10). These strategies have been at most only partially effective in controlling cucurbit powdery mildew with triadimefon. This discrepancy shows that resistance to DMI fungicides is dose-dependent, with higher rates often providing adequate control of strains with reduced DMI sensitivity. Whether this higher rate will be economically feasible in practice depends on the intrinsic activity of the DMI fungicide in question. DMI fungicides differ in their intrinsic activity. Triadimefon is one of the first DMI fungicides. Its intrinsic activity is lower than that of other DMI fungicides like fenarimol. Most triadimefon-resistant strains of $P$. xanthii can tolerate very high triadimefon concentrations $(200 \mu \mathrm{g} / \mathrm{ml})(15)$, making it uneconomical to control them by increasing the triadimefon rate. In contrast, $8 \mu \mathrm{g}$ of fenarimol per $\mathrm{ml}$ was the highest $\mathrm{ED}_{50}$-value found for Venturia inaequalis, and there appeared to be a biological limit to the level of DMI resistance this fungus can acquire. Thus a high fenarimol rate appeared to be feasible to control this fungus (10).

For cucurbit powdery mildew, the high DMI rate and multi-site contact fungicide strategies probably would have contributed more to managing triadimefon resistance in earlier stages of resistance development. The current study was started 9 years after triadimefon was registered in the United States when pathogen strains with a high level of resistance to triadimefon were already widespread (23). The same strategies may also be more effective with DMI fungicides other than triadimefon that have a higher intrinsic activity, such as myclobutanil and propiconazole. In contrast to triadimefon, the highest tolerated concentrations were only $20 \mu \mathrm{g} / \mathrm{ml}$ for myclobutanil and $5 \mu \mathrm{g} / \mathrm{ml}$ for propiconazole in this and a previous study (23). Chlorothalonil effectively controls cucurbit powdery mildew where deposited, which is mainly the upper leaf surfaces (18), and thus it is a suitable companion contact fungicide to use for resistance management.

Combination programs using more than one fungicide have been significantly better for controlling cucurbit powdery mildew than single-product programs for triadimefon, chlorothalonil, and benomyl. Triadimefon was more effective when applied with either benomyl or chlorothalonil in Delaware in 1996, despite the fact that benomyl alone was ineffective (4). More effective control was achieved when the benzimidazole fungicide Topsin $\mathrm{M}$ (cross resistant with benomyl) was included in a fungicide program with triadimefon and chlorothalonil (Reach) in
Virginia in 1996 (2). This combination program was significantly better than chlorothalonil alone in Virginia (1) and in New Jersey (9) in 1995. Either triadimefon or benomyl applied with chlorothalonil was significantly better than either triadimefon or chlorothalonil applied alone, which were the least effective treatments in Ohio in 1996 (26). Triadimefon plus benomyl was as effective as myclobutanil in 1995 and 1996 in California $(7,8)$.

Conclusion. Successful management of cucurbit powdery mildew with systemic fungicides registered at the time of this study in the United States is challenged by the occurrence and yearly dynamics of resistance to triadimefon and to benomyl. It is not possible to predict the efficacy of these fungicides based on the frequency of resistant strains the previous year. One application of these fungicides causes the pathogen population to shift within just 2 weeks to predominantly resistant strains. As a consequence, subsequent applications do not provide additional disease control. Moreover, the initial frequency of resistant strains can be sufficiently high that control failure occurs following even the first application. At the completion of this study, triadimefon and benomyl were still recommended for managing powdery mildew because of the importance of systemic fungicides for control of powdery mildew on abaxial leaf surfaces and the lack of registered alternatives. Their application, however, should always be made in combination with multi-site contact fungicides to manage resistance and to obtain some powdery mildew control in the event that the initial frequency of resistant strains is high. Although chlorothalonil controls powdery mildew poorly on abaxial leaf surfaces due to poor spray deposition, it did contribute to resistance management on abaxial surfaces as triadimefon-resistant strains were at a lower frequency when chlorothalonil was added to a triadimefon or a triadimefon alternated with azoxystrobin fungicide program $(18,25)$. Proper application timing using an IPM schedule is critical to ensure the one application of triadimefon or benomyl, which will shift the population to predominantly resistant strains, is made after the action threshold is reached, which is when it will have the greatest impact on sensitive strains, but before the pathogen population becomes too large to be suppressed.

The occurrence of resistance to triadimefon and benomyl and the lack of seasonlong control with these fungicides (with at most one application effective) in this and previous studies (15) reveals the need for new systemic fungicides to be registered in the United States. It is prudent to implement resistance management strategies when new fungicides at risk for resistance development are registered rather than waiting for resistant strains to appear. Strategies include applying systemic fun- 
gicides with multi-site contact fungicides, improving spray coverage on abaxial leaf surfaces, limiting the number of applications of systemic fungicides, alternating among effective systemic fungicides with different modes of action, and avoiding curative (eradicant) applications on well established pathogen populations by using an IPM scouting protocol or forecasting system. In addition, new DMI fungicides should be used at concentrations sufficient to obtain complete control of triadimefonresistant strains, minimizing the chance for selection of less sensitive strains. High rates were effective for managing fenarimol resistance in Venturia inaequalis (10) and have been recommended for other fungi (29). Although addition of a contact fungicide may manage resistance to an effective fungicide (such as myclobutanil or propiconazole), it is not expected to provide a detectable increase in disease control in early stages of resistance development, because strains with reduced sensitivity to the at-risk fungicide would be at too low a frequency in the pathogen population to affect disease development.

\section{ACKNOWLEDGMENTS}

This work was supported by ISK Biosciences, Mentor, $\mathrm{OH}$, the New York State College of Agriculture and Life Sciences (Hatch Project 153445) and the New York State Integrated Pest Management Program. We thank S. Butterworth, M. Creighton, B. Dosiak, W. Hennenlotter, J. Kim, J. Keller, J. Platte, M. Ratcliff, S. Sanok, K. Sheehan, B. Shelton, H. Staniszewska, and W. Wilson for technical help. Bayer, Kansas City, MO, E. I. duPont de Nemours, Wilmington, DE, ISK Biosciences, and Agway, Elizabethtown, PA, provided fungicides and seed used in these studies. M. Hausbeck, W. A. Sinclair and H. L. Ypema critically reviewed this manuscript before submission. Mention of a proprietary product does not constitute endorsement by Cornell University or imply lack of efficacy of similar products not mentioned.

\section{LITERATURE CITED}

1. Alexander, S. A., Baldwin, R. E., and Waldenmaier, C. M. 1996. Evaluation of fungicides for control of diseases of pickling cucumbers, 1995. Fungic. Nematicide Tests 51:112-113.

2. Alexander, S. A., and Waldenmaier, C. M.
1997. Evaluation of fungicides for control of diseases of cantaloupe, 1996. Fungic. Nematicide Tests 52:103.

3. Damicone, J. P., Filonow, A. B., and Evans, R. A. 1995. Comparison of fungicides, biocontrols, and bicarbonate+oil for control of powdery mildew of pumpkin, 1994. Fungic. Nematicide Tests 50:142.

4. Everts, K. L., and Mulrooney, R. P. 1997. Evaluation of fungicide regimes for the control of powdery mildew on cantaloupe, 1996. Fungic. Nematicide Tests 52:104.

5. Hausbeck, M. K., and Kusnier, J. J., III. 1995. Evaluation of fungicides for control of foliar fungal diseases of pumpkins, 1994. Fungic. Nematicide Tests 50:143.

6. Hausbeck, M. K., and Kusnier, J. J., III 1996. Evaluation of fungicides for control of foliar diseases of squash, 1995. Fungic. Nematicide Tests 51:147-148.

7. Holmes, G. J., Paulus, A. O., and Aguiar, J. L. 1997. Evaluation of fungicides for control of powdery mildew of muskmelon, 1996. Fungic. Nematicide Tests 52:114.

8. Holmes, G. J., Paulus, A. O., and Vilchez, M. 1997. Fungicide efficacy for control of muskmelon powdery mildew, 1995. Fungic. Nematicide Tests 52:115.

9. Johnston, S. A., and Phillips, J. R. 1996. Evaluation of fungicides for the control of foliar diseases on cucumbers, 1995. Fungic. Nematicide Tests 51:114

10. Koller, W. 1996. Recent developments in DMI resistance. Pages 301-311 in: Modern fungicides and antifungal compounds. H. Lyr, P. E. Russell, and H. D. Sisler, eds. Intercept Ltd., Andover, Hampshire, U.K.

11. Matheron, M. E., and Porchas, M. 1996. Comparison of fungicides for control of powdery mildew of cantaloupe, 1995. Fungic. Nematicide Tests 51:103.

12. Matheron, M. E., and Porchas, M. 1997. Comparative efficacy of fungicides for management of powdery mildew on cantaloupe, 1996. Fungic. Nematicide Tests 52:105.

13. McGrath, M. T. 1995. Evaluation of fullseason and reduced-sprays fungicide programs initiated after disease detection for managing powdery mildew of pumpkin, 1994. Fungic. Nematicide Tests 50:146-147.

14. McGrath, M. T. 1996. Evaluation of fungicide programs initiated after disease detection for managing powdery mildew of pumpkin, 1995. Fungic. Nematicide Tests 51:143-144.

15. McGrath, M. T. 1996. Increased resistance to triadimefon and to benomyl in Sphaerotheca fuliginea populations following fungicide usage over one season. Plant Dis. 80:633-639.

16. McGrath, M. T. 1996. Successful manage- ment of powdery mildew in pumpkin with disease threshold-based fungicide programs. Plant Dis. 80:910-916.

17. McGrath, M. T. 1997. Evaluation of fungicide programs initiated after disease detection for managing powdery mildew of pumpkin, 1996. Fungic. Nematicide Tests 52:138.

18. McGrath, M. T. 2000. Evaluation of fungicide programs for managing powdery mildew of muskmelon, 1999. Fungic. Nematicide Tests 55:176-177.

19. McGrath, M. T., and Shishkoff, N. 1997. Dynamics of fungicide resistance and impact on control of cucurbit powdery mildew. (Abstr.) Phytopathology 87:S64.

20. McGrath, M. T., and Shishkoff, N. 1999. Evaluation of biocompatible products for managing cucurbit powdery mildew. Crop Prot. 18:471-478

21. McGrath, M. T., and Staniszewska, H. 1994. Efficacy of fungicides applied preventively or following disease detection for managing powdery mildew of pumpkin, 1993. Fungic. Nematicide Tests 49:142.

22. McGrath, M. T., and Staniszewska, H. 1996. Management of powdery mildew in summer squash with host resistance, disease threshold-based fungicide programs, or an integrated program. Plant Dis. 80:1044-1052.

23. McGrath, M. T., Staniszewska, H., Shishkoff, N., and Casella, G. 1996. Fungicide sensitivity of Sphaerotheca fuliginea populations in the United States. Plant Dis. 80:697-703.

24. McGrath, M. T., and Thomas, C. E. 1996. Powdery mildew. Pages 28-30 in: Compendium of Cucurbit Diseases. T. A. Zitter, D. L. Hopkins, and C. E. Thomas, eds. American Phytopathological Society, St. Paul.

25. McGrath, M. T. and Shishkoff, N. 2001 Managing resistance to demethylation inhibiting (DMI) fungicides in cucurbit powdery mildew. (Abstr.). Phytopathology:(accepted).

26. Riedel, R. M., Stuart, M., and Schmittgen, M. 1997. Chemical control of powdery mildew on pumpkin, 1996. Fungic. Nematicide Tests 52:169

27. Shamiyeh, N. B., Straw, R. A., Mullins, C. A., and Southards, C. J. 1997. Foliar fungicide applications for control of mildews on pumpkins, 1996. Fungic. Nematicide Tests 52:170.

28. Shishkoff, N. 2000. The name of the cucurbit powdery mildew: Podosphaera (sect. Sphaerotheca) xanthii (Castag.) U. Braun \& N. Shish. comb. nov. (Abstr.) Phytopathology 90:S133.

29. Ypema, H. L., Ypema, M., and Gubler, W. D. 1997. Sensitivity of Uncinula necator to benomyl, triadimefon, myclobutanil, and fenarimol in California. Plant Dis. 81:293-297. 